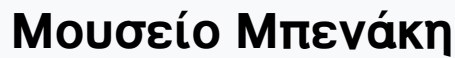

A Singular Antiquity: Archaeology and Hellenic Identity in Twentieth-Century Greece

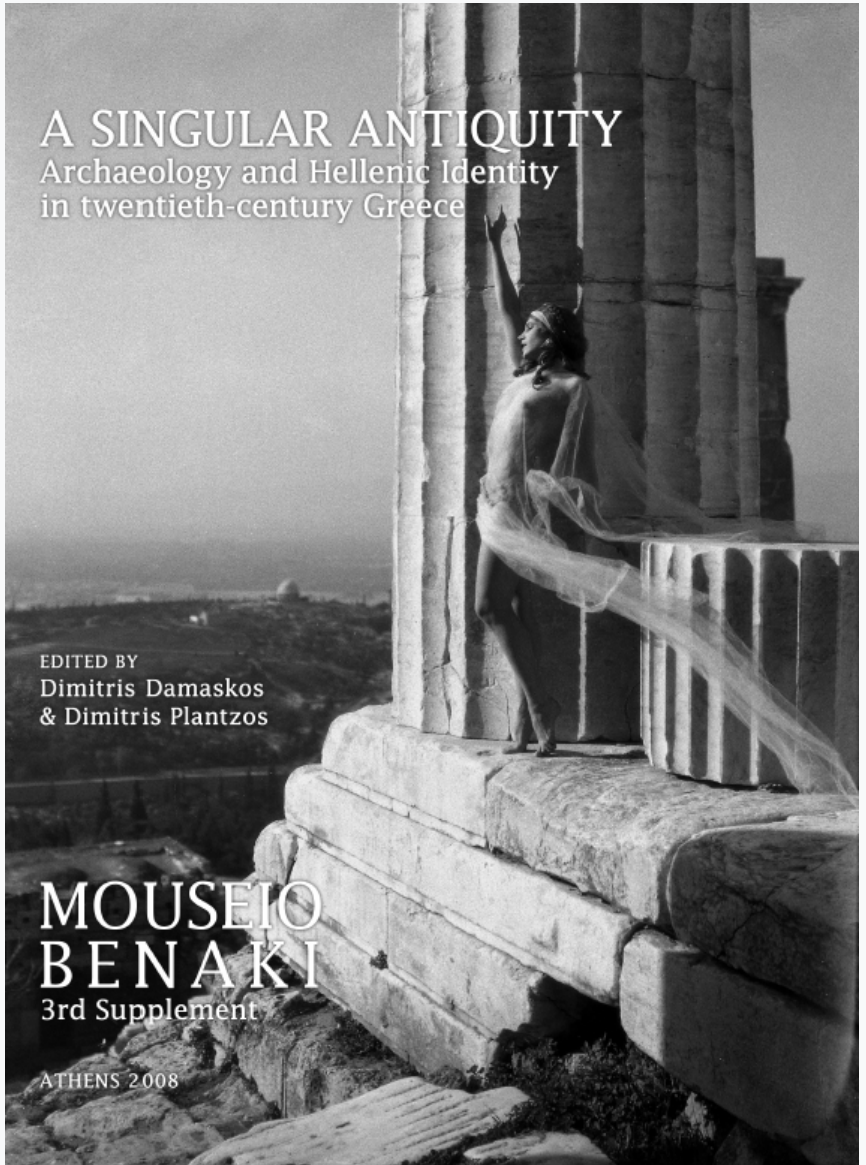

The dead hand of Philology and the archaeologies of reading in Greece

Vangelis Calotychos

doi: $10.12681 /$ benaki.18011

Copyright @ 2018, Vangelis Calotychos

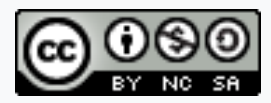

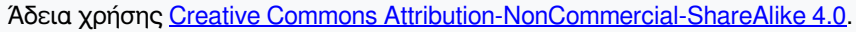

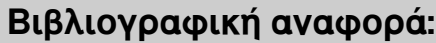

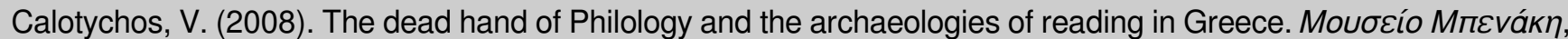
237-252. https://doi.org/10.12681/benaki.18011 


\section{The dead hand of Philology and the archaeologies of reading in Greece}

'IN 1908, CLASSICAL philology was still important enough to provoke a satire', or so, Anthony Grafton contends, was the case if one consults Ludwig Hatvany's Die Wissenschaft des nicht Wissenswerten, which was published in that year. For, in this work, Hatvany caricatures the deathly seriousness of young philologists and assails their tendency to become entangled in facts that obscure the text in hand and critically sap its vitality and drain the text of its meaning. According to Hatvany, the students 'did not read (lesen) ancient literature, they read it to pieces (zerlesen) in their frenzied search for raw materials from which to make lexica and handbooks - but never a new vision of the past.'. So inclined, the philologists of the day did not aspire to realize the main tenets of Altertumswissenschaft, or the 'science of antiquity', and above all, 'the demand that the student pay equal attention to every aspect of the Greek and Roman worlds and fit every text into an elaborate political, social, and material context.'

In 2008, one hundred years on from Hatvany's satire, so diminished is classical philology's place in the panoply of reading practices in Western academe that it is doubtful that satirizing philology would get much of a rise out of the general or critical reader. For, while the posture of close reading may in some sense still lie at the heart of much reading - deconstruction also relied on close reading, after all - it is not philological. The overall and most predominant terms of textual practice have changed so markedly within academia that philology has fallen into specific usage within departments of classics and, even there, exists only in ever more embattled pockets. However, concerns over the relations between text and context
'The doctrine of the establishment of a pure text as a pre-condition for serious work (a pre-condition that is never fulfilled, as each generation finds reason for dissatisfaction with a text), strongly resembles, and is probably derived from, the dead hand of classical studies of a now (fortunately) almost extinct type'.

Michael F. Hendy, Studies in the Byzantine Monetary Economy, c. 300-1450(1985) 12.

that Hatvany underscores in 1908 remain as intense today as ever, as philologists nowadays defend the text from wanton purveyors of contexts.

Of course, it is not quite so clear-cut whether a satire of philology and philologists would fall on such deaf ears in Greece, for philology there still holds more than its fair share of sway beyond classical philology in literary and in intellectual associations as well as in academia as a whole. In Greece, the reading public still accords some respect to the philologist's serious-mindedness. In part, this regard has been maintained through the philologist's role as guardian of the language, which, as the quintessential index of Greek continuity, must be forever reinforced by the unstinting performance of originary discourse. Comparatively speaking, then, the term 'philology' has more than its fair share of currency in Greece. Indeed, it remains in accepted usage as the staple marker for Greek literary studies, indeed literary study, with a tenacity unrivalled in much of Western Europe. ${ }^{3}$ Today philologia is used primarily in the sense of 'study of literature' (as opposed to logotechnia, the practice of literature), and as such is used by all university departments of literary studies in Greece, both Greek and foreign. Indicatively, such departments often retain the word 'Philology' in the English translation of their departmental name. Moreover, the impact of literary and critical theory post-1960 which severely wounded the modern handmaidens of philology - formalism, structuralism, and New Criticism - in Western academia, albeit only in some instances after a bruising encounter, has been less dominant in Greece. Whereas the kinds of literary practice in Greek journals 
bear the mark of this theoretical turn, many university departments still cling to a philological bias. From a multi-disciplinary perspective, one might argue that, in Greece, the theoretical turn in the humanities has been less forthcoming in literary studies than in other areas of the humanities and social sciences. Philology has proved itself more durable and, at times, positively oblivious to institutional, philosophical, political and social challenges - a tough customer, so to speak, and not one to be the butt of anyone's satire.

This gives us pause for thought. Why have the methods and reading strategies associated with philology proved so durable? This article considers this durability not within the narrow confines of my own discipline of literary and cultural studies in Greece and abroad, but rather through the relation of philology to archaeology and the study of antiquity. In considering such matters, I do so neither with any authority in the field of the epistemology of archaeology, nor do I follow recent debates within the discipline itself particularly closely. Rather, I observe here the way such disciplines engender certain reading practices that have favoured specific combinations of text and context. After all, not only philology and archaeology but also folklore developed in the late eighteenth and nineteenth centuries in Greece as critical discourses for the foundation of Romantic nationalism, the conceptualization of modern Hellenism, and the ideological justification of the modern Greek state. While surveying the historical conjunctures that supported this triumvirate of epistemological practices in Greece, there is no need to rehearse here the well-attested historical narrative of these disciplines' emergence in Greece. The case for folklore's role in Greek nation-building was made quite comprehensively by Michael Herzfeld in his book Ours Once More as far back as 1986. In this work, Herzfeld stresses how the 'official endorsement of folklore studies partly rested on the assumption that they were of an archaeological nature. ${ }^{4}$ Therefore, my paper considers how in Greece, despite changes in epistemological practices and a realignment of such human sciences throughout Western academia, philology (and folklore for that matter in relation to anthropology) have remained such durable institutions in Greek critical practice. Most notably, the persistence of philologically-based modes of reading, priding themselves on a resistance to critical and cultural theory at an institutional level, remain especially prevalent, and some would say retrogressive. Whereas, in other disciplines in Greek universities, especially in the social sciences and history and even in cultural anthropology's slow predominance over folklore studies, the adoption of more theoretical modes of reading and interpretation has become more widespread than it has in literary and cultural studies and in archaeology. Why the delay in unhanding 'ourselves' from the deathly grip of philology? My working hypothesis will be that philology and archaeology exemplify and condition biases of a reading reflex that has marked Greek literary and cultural interpretation and that owes its form largely to the nexus of philology-classics-archaeology in national formation in the eighteenth and nineteenth centuries.

\section{Archaeologies of reading and writing}

It is properly serious-minded to begin on a philological point. The word philology submits to a range of meanings. Margaret Alexiou has offered an economical summary of the term and its usage over time. 5 In ancient Greek, these include 'love of argument and reasoning' (in Plato); 'learned conversation' (in Antigonus of Carystus); and 'love of learning and literature' (in Isocrates and Aristotle). It reentered the Greek vocabulary during the late seventeenth century as the equivalent of Latin litteratura, inclusive of all kinds of writing (history, theology, philosophy, even the natural sciences) until, in the eighteenth century, it was narrowed down to 'imaginative, creative writing', a sense it retained until 1886, when a new term, logotechnia ('wordcraft') was coined by the demoticists in their attempt to overwhelm the katharevousianoi or purists. In many ways this development fostered a distinction that matched one prevalent in England a century earlier, at the end of the eighteenth century, where an erudite scholar with a love of learning and literature might be termed a 'philologist' while a well-rounded gentleman enamoured of writing and discourse might be engaged with 'literature'.

In general, classical philological practice chiefly signified the technical and systematic study of words, language, grammar, rhetoric and poetics in the Graeco-Roman or classical world. However, during the nineteenth and into the twentieth century the field in Europe and America segmented into the areas of classical philology (Classics), cultural philology (Comparative Linguistics), and general philology (Literary Studies). These disciplinary transfor- 
mations had different effects in different countries and 'literary' studies as a historical discipline was, to varying degrees, allied to yet distinct from the more descriptive sciences of philology and rhetoric. There can be little doubt that in Greece, the first of these areas, classical philology, exercised a great impact on the terms of textual practice implemented in the area of linguistics as well as in the field of literary studies. Indeed, just as the currency of the term philologia in Greece owes a debt to the German tradition towards the end of the eighteenth century when Philologie became associated with Altertumswissenchaft, so too did the reading practice that went with it. And while today, in colloquial terms, the word in its plural form - filologies - has the pejorative sense of 'clever but useless and irrelevant talk or chatter', the singular carries with it a certain sobriety - some would say, a deathly seriousness. Some of this seriousness has rubbed off on modern literary studies in Greece where anti-philological reading practices are more likely to be seen as frivolous or suspect than is generally the case elsewhere.

Both philology and archaeology in Greece grew out of the interest in the ancient world. The former established itself at the end of the eighteenth century and the latter, somewhat later, in the nineteenth century. And, since a large proportion of texts came from archaeological contexts, philological tradition constituted a major resource for historical archaeology. From the outset therefore classical archaeology was dominated by scholars trained in philology, even though, strictly speaking, philology concerned itself with monuments in linguistic forms. By the time archaeology emerged in Greece, philology had established itself as a rigorous discipline.

It was the philologist, archaeologist and politician Robert Wood who first proposed that one 'read the Iliad and Odyssey in the countries where Achilles fought [...] and where Homer sung.' His instantly popular Essay On Homer (1767) established the link between travel and classical poetry: 'the Iliad has new beauties on the banks of the Scamander plain, with Homer in our hands'. Eventually, Wood's translated work on Homer fell into the hands of Friedrich August Wolf in Germany. In his Prolegomena ad Homerum (1795), he set about to 'professionalize' Wood's dilettante wanderings in the language of Altertumswissenschaft. In time, through his working friendship with Wilhelm von Humboldt, the Greeks and antiquity were placed at the centre of Bildung, the moral and educational principle behind the neo-humanist pedagogy of the Prussian Gymnasium and, eventually, the formation of the Prussian state. ' Like Winckelmann's History of Ancient Art (1764) before it, Wolf's scholarship separated Greeks and Romans from other peoples and elevated them above from history itself. ${ }^{8}$ Humboldt and others reflected and built on such exceptionalist thinking, for, as Bernal has argued, the Bildung project 'saw in German education and scholarship a third way that broke away from the stagnation of Tory and Whig England while avoiding French radicalism.' With the support of the Prussian aristocracy, Bildung projected the potential fragmentariness of ethnicity, history, and culture into a totalizing and centralized heterotopia that was the Ideal Greece, one that rewrote the ancient ideal, through the disciplines of classics, philology and archaeology and in the terms of German and European modernity.

Susan Marchand, in her Down from Olympus, very convincingly details just how Wolf took an aristocratic ideal and developed 'a counterexample to [its] crass materialism and self-indulgence' buoyed up by 'his faith in the power of philological study to instil self-discipline, idealism, and the nobility of character'. ${ }^{10}$ The Greek psyche would be pursued and understood in linguistic, grammatical and orthographical detail. In 1809, Wolf accepted the first professorship in Altertumswissenschaft at the University of Berlin, where, interestingly enough, Humboldt had expressly placed philology in the Faculty of Arts in order to free 'the humanities from the dead hand of scholastic theology." Wolf's methods would prevail. Zealously, he immediately urged his students to incorporate numismatic and epigraphical materials into their work. Later on, he amplified his methods and maintained that Altertumswissenschaft 'encompassed twenty-four disciplines, from grammar to geography, all of which, theoretically, the student should master in order to help decipher the evidence given by a text. Wolf differentiated between six "first-class" disciplines (linguistic, metrical and grammatical) and eighteen belonging to the "second class" (including numismatics, history, geography, and several kinds of archaeology. ${ }^{12}$

The resulting establishment of the practice of antiquity had the effect of linking philology to all manner of other forms of inquiry, hierarchizing disciplines but also prioritizing textual scholarship. The textual criticism of the philologists provided an impetus toward writing-related activities, and this influenced archaeological practices. To 
be sure, such activities had existed in Greece earlier, before the Romantic age. From the age of Louis XIV, figures such as Paul Lucas and Dom Bernard de Montfaucon sought out coins, busts, statues, bas reliefs, and inscriptions in their expeditions. ${ }^{13}$ Jacob Spon, the most methodical of seventeenth-century travellers to Greece, relied on classical textual sources to seek out and understand monuments and sites. He was especially drawn to inscriptions, so much so, in fact, that the last of his three-volume Voyage d'Italie, de Dalmatie, de Grèce, et du Levant, fait aux années 1675 et 1676 is devoted exclusively to inscriptions. Another member of the French Académie des Inscriptions et BellesLettres, the merchant Father Fourmont plundered Athens, Attica, and the Peloponnese in 1729 for inscriptions and bas reliefs, and claimed to have collected 300 bas reliefs and 2600 inscriptions. ${ }^{14}$ However, while classical archaeology had focused on inscriptions since the Renaissance, it was in the first half of the nineteenth century that large numbers of texts from archaeological sites outside the classical world - hieroglyphs, cuneiform tablets, and early Indian inscriptions - were excavated and rendered decipherable for philological and historical study. ${ }^{15}$ Certainly the hubbub over the decipherment of the Rosetta Stone fuelled the excitement over the attempts of philological analysis to unlock the most profound and exciting of human mysteries. Consequently, there was a ferment of activity related to the identification of ancient sculptures and the interpretation of vase paintings.

Parenthetically, it should be mentioned that this graphocentric trend dovetailed with other prevalent genres, not least travel-writing. It gave rise to the penchant for plotting the ancient topography of Greece onto its modern territory. Many participating archaeologists in effect were continuing a politics of 'landscape writing' that, as a tradition of Hellenism, had begun in the previous century with Robert Wood. At this time, gentlemen-scholars made casual and dramatically unscientific forays into antiquity; at the dawn of the Romantic age, nostalgia, loss, a lost childhood, ruins, and the verses of the exemplary 'unletter'd Muse' Homer could all be combined in a trip to Greece. In time these traits would be instrumentalized in a forceful manner.

There were two tendencies behind travel to Greece: on the one hand, a dilettante, at times opportunistic, form of travel to Greece which saw what some would call the 'rescue' and others the 'abduction' of marbles and classical symbolic capital. Fragments of the past were whisked off to the 'safety' and 'freedom' or, alternatively, to the 'gloom' or 'captivity' of the museum. Notoriously, the Ottoman firman issued to Lord Elgin permitted his agents not only to erect the appropriate scaffolding on the temple of Athena so as to sketch it, but actually to make off with 'inscriptions or figures. ${ }^{16}$ In this form of tourism, practised mostly by the English and French (but not by the Germans), Greece became a text to be read in philological terms - for the bibliophile Lamartine, 'Greece is a book whose beauties have faded because it was read to us before we were able to understand it $^{{ }^{117}}$ - its pieces of land read as prose fragments that each in turn memorialized a segment of space and related it to the grander inter-text of classical Greek literature. ${ }^{18}$ On the other hand, the Germans, who did not venture to Greece - 'neither Winckelmann, Lessing, Goethe, Schiller, nor Hölderlin ever saw Greece' ${ }^{19}$ - visited not the sites themselves, but, like the majority of Heyne's students on their Grand Tour, only the art galleries and museum collections of Europe. (In the late eighteenth century, travel had been made too hazardous by the Napeolonic campaigns.) These peregrinations supplemented the work done at the university where catalogues, encyclopaedias, plaster casts, and glyptographies, copiously annotated with notes from ancient authors, were key teaching tools: 'engravings, gems, and coins were what those who never left Germany most easily and profitably studied of classical culture'. ${ }^{20}$ Often, these two tendencies became one and the same: in one notorious instance, in 1784, the Comte de Choiseul-Gouffier sent Fauvel to Athens to make cast copies of antiquities but also to take what he could get his hands on.

Early classical archaeological practice in Greece, then, was an extension of this tradition as well as a practice heavily invested in text-oriented and philological methodologies. Yet, as Anders Andrén reminds us in a book about the relation of material culture and text in the history and practice of archaeology, such divisions between different archaeological specialities are historical constructions. Consequently, at the moment that the modern Greek state came into being, the combination of philology and archaeology was so determined that classical archaeology provided background knowledge for the philological study of antiquity. ${ }^{21}$ Furthermore, it emerged at a time when 'philological archaeology' was in favour. Christian von Bunsen established one of its principal centres at L'Instituto di Corrispondenza Archeologica in Rome in 
1828. Led by Eduart Gerhard, the centre attracted the philologists F.G. Welecher and T. Panofka, and figures of the stature of Chateaubriand, Léopardi, and Champollion. It extolled practices that also happened to be deeply constitutive of Greek modernity - such as the scientific methods of philology, Winckelmannian aesthetics, and the Grand Tour. ${ }^{22}$ These were championed as the very basis of archaeology, with the express aim that, 'Just as philologists and historians have issued critical editions of documents, so classical archaeologists should publish the artefact collections of the great museums [...]. To this end, the institute set great store by the encyclopaedic publication of its findings in bulletins, annali, and monumenti. ${ }^{23}$

Not surprisingly, then, the earliest of archaeological bodies in Greece, the Filomousos Etaireia, established in 1813 , before the establishment of the nation-state, resolved in its constitution to assist in 'the discovery of antiquities and the collection of inscriptions on stone. ${ }^{24}$ Later, in 1829, the state's first museum on Aegina was charged with collecting all antiquities on Greek territory that might contribute to the progress of philology and the arts ${ }^{125}$ The Greek Archaeological Service was established in 1833 as one of the state's first functioning bodies and remains one of the oldest 'national', state-run archaeological services in Europe. The Archaeological Society at Athens followed soon after in 1837. During these early years, according to Vasileios Petrakos:

'the first archaeologists, and especially Pittakis, ${ }^{26}$ acted as collectors and not academic archaeologists. They were interested in the beautiful, the historical, the uniquely classical, they were concerned with and protective of inscriptions, whose first publication they relished. Vases interested them only to the degree that they depicted scenes and were also well preserved and of exceptional artistic quality. This attitude persisted in Greek and foreign archaeologists alike for many decades. ${ }^{27}$

Interestingly enough, in the Greek Archaeological Service's journal, the Ephemeris Archaeologike first published in 1834, 'the vast majority of the objects published [...] were stone inscriptions' and, somewhat later, the importance of these inscriptions was often cited as one of the justifications for the demolition of post-classical buildings and for much of the archaeological activity. ${ }^{28}$ However, '[this] emphasis on inscriptions is not simply explained by the role of Greek language as a proof of national continuity, or by the training of scholars who published them in the philological tradition,' suggests Hamilakis, 'it is rather the combination of the distinctive materiality, permanence, and physicality of the medium (the stone), with the evocative and meaningful role of the message, that is, words in Greek letters, that are legible to the educated modern Hellenes. These were not simply material monuments, but the sacred texts of the new religion.' ${ }^{29}$ This sacrality of material monuments of the word must be understood in its larger cultural context for the same inclination informs so many emergent epistemological discourses in Greece during the course of the nineteenth century. At the height of Romanticism, the concern for the linguistic aspects of texts was well received in Greece. For Greeks sought solutions to their fledgling nation's identitarian quandaries in their language. They evangelized continuity by setting great symbolic and ideological store by the unbroken existence of the Greek language over time. Through it, Greeks sought to compensate for the perceived dearth of chirographic traces left behind after Ottoman rule on Greek soil (or, to be precise, that part of Greek soil incorporated into the new Greek state). ${ }^{30}$ And so, upon achieving statehood (and just before it, in fact), they undertook to set down in writing, to monumentalize, the existence of those parts of their tradition that had been left unwritten and whose absence threatened to undermine the claim to continuity. In other words, they brought together the previously described philological approach with this monumentalizing zeal to draw together scientifistic/philological rigour and irrefutable material proof against those who would cast doubt on this past. Traces of this approach pervade the constitution of the disciplines of folklore, linguistics, history, and archaeology during the course of the nineteenth century. In folklore, oral performance was textualized and anthologized, variants of songs and folktales standardized as 'monuments of the word' $;^{31}$ and, in response to the challenges posed by Fallmerayer's questioning of Greek racial purity in his treatises of the 1830s, ethnographic observations of ritual and practice were energetically noted down in what was to become the discipline of laographia (folklore studies)..$^{32}$ In philology and in language, forms were codified and regionalisms standardized and centralized. By the last quarter of the nineteenth century, this trend established itself across disciplines in the university. So much so that 
neo-grammarian principles informed the methodologies that Georgios Chatzidakis brought from Germany to the Chair in Linguistics, at the University of Athens in 1881. At the same time, in the same influential university but in the discipline of history, Spyridon Lambros, schooled in Germany, enforced strict distinctions between primary and secondary sources in his inaugural lectures in 1875. He inculcated the application of eminently philological methodologies in his tutees by introducing exercises concerning the study and chronology of medieval inscriptions and manuscripts. ${ }^{33}$

The earliest Greek archaeological activities examined monuments promised by ancient sources. And thus, archaeology's secondary or ancillary status derives from its need to serve a pre-existing narrative text. Archaeology provides illustration for accounts based in other sources prior to itself. And so, while the discourse of Hellenism 'had a minimal archaeological component throughout the nineteenth century, ${ }^{34}$ it acted at the behest of written texts for the monumentalization of the written. ${ }^{35}$ Eventually, when, as a discipline, archaeology did drive Hellenism - and this occurred much later in that century - its two chief exponents, Heinrich Schliemann and Arthur Evans, were still very much driven by texts.

In a wider context, the degree to which classical archaeology generally adapts its own narrative to the dictates of written or literary texts may be debatable. Certainly, part of historical archaeology worldwide has grown in association with the quest for new texts. ${ }^{36}$ Often this has been an incentive for excavation. On occasion archaeology has been summoned to provide background material or the realia of life in antiquity - in pursuit of what might be termed 'contexts' - to support 'textual' analysis. Often such knowledge was applied to solve linguistic problems and explain words and texts. In a discipline so heavily informed by philology, linguistic criteria were given preeminence so that 'although the texts were the fruit of archaeological work, they were studied and classified into different genres with little regard to finding context'. ${ }^{37}$ In the process, many dictionaries of extinct historical languages were spawned. And all in all, in each branch of archaeology there remains the question as to whether such activities promoted a 'text-aided archaeology' or an 'object-aided philology'? ? $^{8}$ This may be as prescient and difficult a question to answer, equally for a non-specialist due to an ignorance of the historical and disciplinary evidence as, in all likelihood, for the specialist in the field of Greek archaeology due to his or her discomfiture with the demands of disciplinary self-reflexivity. For the power and self-sufficiency of ethnocentrism and the self-evident force of the ideology of continuity for Greek nationalism and archaeology has left its mark on a singularly untheoretical practice in Greece and on an institutional practice where 'there was indeed very little chance of including in this strict ideological model anything that would not establish a direct continuity with the classical Greek past, since anything else was either disregarded or seen as an unnecessary complication'. ${ }^{39}$ This observation - incidentally made not by a classical archaeologist but by a prehistorian - reflects how the Middle Ages went unrecognized until the late nineteenth century and Byzantine monuments had to wait for the foundation of the Byzantine Museum in Athens in 1914. For, when archaeology did come into its own in Greece in the 1870s, it had been perceived as threatening to Hellenism: 'In the last quarter of the century,' contends Ian Morris, 'all archaeologies of Greece were absorbed administratively and intellectually into classics, and their connections with the emerging broader discipline of archaeology were systematically severed. ${ }^{30}$ The archaeology of classical Greece slowly diverged in theory and method from other archaeologies, including Greek prehistory. Prehistoric archaeology, too, was overlooked if it did not fit as a prelude to the classical narrative. ${ }^{41}$ The ramifications of these epistemological beginnings are evident even today as: 'there are no separate departments of archaeology or separate degrees in archaeology in Greece. Indicative of how archaeology was initially conceived of as a handmaiden to classical philology and ancient history, the departments that offer degrees in archaeology are departments of history and archaeology (or in one case, history, anthropology, and archaeology)'.22 It is telling that the first university textbook to refer to archaeological literature did not appear until 1982.43

Of course, much of this criticism also applies to archaeology beyond Greece's borders. Moreover, in more general terms, the transformation of archaeology from a discipline charged with describing and recording the past - and more and more of a recoverable past at that - to a discipline keen to identify and confront the challenges at the heart of human development found classical archaeology ill-equipped to respond. From the sixties onwards, classical archaeology was 'shielded' from the wider intel- 
lectual changes raised by theoretical anthropology. It remained doggedly empirical and descriptive, ever in the service of ethnogenesis, and unable to embrace a disciplinary method distinct from history and classical studies, let alone the prescriptions of the New Archaeology. ${ }^{44} \mathrm{By}$ 1980 Colin Renfrew had announced the existence of a Great Divide 'between the anthropological tradition in America on the one hand, where the archaeology of the Americas is invariably taught within departments of anthropology, and the classical tradition on the other. So the archaeology of the Old World is in general taught within departments of classics, or in specialist institutes, or in an obligatory and little-regarded component of anthropology. ${ }^{45}$ For Renfrew, the divide emanated from classical archaeology's considerable positivistic record of hard data for classical archaeology - its unparalleled time-depth reach and quality of coverage - on the one hand, and on the other the decidedly more penurious traditions of Other archaeologies - most notably, American archaeology - whose exponents' dismay at their comparatively scant records - according to Renfrew - led them to seek refuge or solace in theory, methodology, and the elucidation of the cultural process of change. Alternatively, to see the same divide through the eyes of another archaeologist, Anthony Snodgrass, twenty years later and from a very different perspective: '[Classical archaeology] is pragmatic and employs no explicit body of theory. Lulled into complacency by the benevolent interest of the educated public, it is content with the goal of description. It describes everything, analyzes and synthesizes a restricted range of aspects, and explains nothing. ${ }^{46}$ In disciplinary terms, then, whereas the New Archaeology sought out cross-disciplinary synergies for the purpose of revealing social and artistic trends, the field of classical archaeology was largely content to indulge in artistic evaluation and classification. In this, it recalled prevalent practices in art history, a fact not overlooked in Snodgrass' analysis: 'the appreciation that the visual arts are directly shaped by the society for which they are practiced, and that they therefore directly reflect the nature of that society - these are not deeply ingrained in archaeological thinking. ${ }^{47}$ Historically and institutionally, classical archaeology, like art history (and philology), was ill-equipped to move beyond its strength (as defined by Renfrew) - i.e. the accumulation and taxonomy of data - to prioritize or admit to the ordering of material as regards its relevance to historical process. In Greece, when some inroads were made in this respect, it was no surprise to find that the importance of material culture and the social embeddedness of theory issued from the strong Marxist tradition post- 1960 that had left its mark most forcefully elsewhere, in the field of sociology. ${ }^{48}$

In many ways archaeology, like philology, was facing the same problem of text and context adumbrated by the references to Hatvany at the beginning of its paper, and so it is to reading practice and the relation of text and context that this article returns.

\section{Philologies of reading}

The first section of this article took a philological approach. It was then followed by a historical section that now makes way for a reflexive consideration of the terms of reading practice that mark philology and are very reminiscent of those also favoured by archaeology. These will be considered in their microscopic (textual) and macroscopic (contextual) aspects. To my mind, the discussion of common archaeologies or genealogies of reading between disciplines is crucial for setting out the ways a cultural critic, rather than a philologist, sees how such strategies served nationalism two hundred years ago and yet are ill-equipped to cope with the changing form of modern society today.

Admittedly, a critic of modern literature and culture like myself may not be ideally suited to understanding the ways archaeologists read cuneiform tablets, papyri, and parchment. Neither does such a critic resort to the methods of paleography or codicology nor is he or she likely to share the philologist's obsession with a prior materiality. For how else might one describe the philologist's explicit, ritualistic prioritization of the text over the context? The most fervent philologist acknowledges how forms of interpretation intersect the philological act, as there is more to philological activity than looking at words individually and determining meaning on the basis of earlier and later evidence. In other words, good philology is not limited to textual criticism and editing, metrical and stylistic analysis or commentary. Good philology's reading practice draws on cultural history, archaeology, epigraphy, social science methodology, religion, ritual, and archaeology. Historically, from Wolf's time, a vein in the field of philology has grappled with its literary hermeneutic responsibilities. 
Indeed, early debates on the issue in German philological circles at the turn of the nineteenth century saw such central figures as Ast, Schelling, Goethe, and Hegel lean toward emphasizing interpretation over the grammatical and linguistic aspects of their practice..$^{49}$ Daniel Selden has sketched an extant hermeneutic tradition within philology, one taken up later by such figures as Schleiermacher, Marx, Nietzsche, and Freud long before more recent critical-theoretical trends succeeded it and provoked considerable resistance and new levels of antagonism..$^{50}$

Greek philology has been no less antagonistic than archaeology to contemporary criticism and theory. It has also been singularly unwilling or uninterested in theorizing its own practice, believing that its perceived scientifism, objectivity, rigour, and common-sensical interpretative basis speak for themselves. Though philology in Greece has retained a larger stake in literary studies than its counterpart in Anglo-American criticism, it has also manifested less of an inclination to be drawn into a consideration of its principles through a sustained exchange with theory. It may be useful for our purposes here to consider the claims of philology as these were set out at a specific cultural moment in the United States, in the early nineties, when the 'culture wars' impinged most threateningly on strategies of reading. By so doing, we may rehearse arguments often deployed, but not often comprehensively set out, in the interface between philology and contemporary criticism in Greece.

For many philologists, the claim to a primacy for their discipline depends on an explicit hierarchization of text over context, conditioned by their belief in the 'close proximity' of their text to their reading. For example, according to the philologist Richard Thomas, philology is a 'relationship of "affection," "respect," and "close proximity to a text" [that] necessarily involves reverence on the part of the critic towards the text; that is, it involves a separation of literature and criticism, as being distinct in kind and therefore beyond competition'. ${ }^{51}$ For philology bases itself on a notion that it is basic or foundational and that its knowledge serves as a precondition for any further, and so secondary literary-interpretative exercises, not to mention metacritical, theoretical work. Consequently, for the philologist, any perceived second order of reading is regarded as extraneous - in Thomas' chiding words, 'a conceptual impossibility and a grotesquery. ${ }^{52}$ Such reading is less essential (or essentializing) than, not even of the same essence (homoousios) as, the text. So, as Thomas proceeds to describe philology's task, he focuses on the knowable facts about the texts themselves, armed with the knowledge that the questions these very texts generate 'will do the rest'. In the process - 'philology will take what it wants from wherever it wants'. Thomas' definition of philology both endows it with a laissez-faire conscience while retaining some of the austerity won for it by Wolf and his acolytes. The critic's unswerving purpose and professed self-abnegation translates into the critic's Kantian 'disinterestedness' - 'philology will take what it wants' etc. - and a disciplinary self-sufficiency - 'remaining secure in the face of what are essentially pressures from the outside. ${ }^{53}$ In the process, Thomas effectively deposits agency in the text and professes a scientific metaphysics. In so doing, he claims for the field a professionalization and scientifistic objectivity that have groomed American philologists - and this also applies very much to Greek establishment critics - to look askance at philosophically-driven criticism or the kind of self-reflexive theory (often cited shorthand as 'deconstruction') so typical of contemporary anthropological and postmodern theory. Practitioners of such subjective endeavours are deemed morally suspect. In Greece, too often, this perceived lapse into secondary reading is regarded as foreign in provenance and disposition: foreigners or Greek critics in the diaspora are stigmatized as being at one remove from their source, from their language, from their tradition and its Ur-Texts, and hence often geographically but also morally and occasionally sexually suspect. One Greek diaspora critic sums up the stance of such philologists thus:

'Sorely mistaken are they who think that the field [i.e. philology] that has protected Greek letters and language from any foreign theory, every subservient periodical and foreign-sounding term will allow common or garden ideas (and with them their customarily effeminate proponents and Greeklish fellow wayfarers, as is often accused) to threaten the language that knows of no untruth. Even when it is obliged by circumstances to consider issues of sexuality, otherness, interculturalism, comparativism or polysemia, Greek philology knows well how to make these serve, and not threaten, national identity and aesthetics. It knows very well how to make them affirm the deeper Greek character of the literary text. ${ }^{54}$

In summation, while philologists tend to erase subjectivity 
from their selves and their own practice, they more or less concurrently project such subjectivity onto the motivations and assumptions of other non-philologist critics. Of course, this partially explains why the absence of a theorization of philological practice is seen as so philosophically consistent by most philologists. ${ }^{55}$ After all philology demonstrates a corrective impulse: it proposes the emendation and correction of texts that might be seen as 'corrupt' and often does so with the moral certainty of linear progress or material textual accumulation that represses the Otherness to be found in the text. By implication, it also entails the moral correction of cultural critics, theorists, and diaspora critics who, literally and metaphorically, have been away from home too long. ${ }^{56}$

Ultimately, philology is what it is not or what it leaves out. And thus, to reject the foundational character of philology is to show how secondary realms of reading may prove useful to our understanding and how they may remain nonetheless foundational (if foundationalism is to be retained as a category even as it performs its swan song). In the same volume that hosted Richard Thomas' previously cited reflections, entitled On Philology, the critic Jonathan Culler embarks on just such a venture. Culler maintains that 'the notion of philology as a basis which is somehow prior to literary and cultural interpretation is an idea that one should seriously question, and an idea, moreover, that philology itself, in principle as well as in practice, provides us with the tools for questioning..$^{57}$ For, at the microscopic level of textual practice, philology's reconstructive project must tap into its tension with the aesthetic and ideological underpinnings that have the effect of critiquing that very process of construction. With due diligence at a meeting attended by a number of eminent philologists, Culler transposes this debate to a more macroscopic level when he affirms that 'there might be the question of how far the construction of philology as a scientific discipline in the late eighteenth century and early nineteenth century was complicitous with or was based on the invention of an Aryan Greece that would serve as origin for modern cultures in northern Europe'.58 Writing at a time when the debate over Martin Bernal's Black Athena: the Afro-Asiatic Roots of Hellenic Civilization (1987) was in full swing and when deconstruction was still deemed a credible 'threat', when the debate over the cultural politics of liberal education, scholarship, race, and multiculturalism in the late eighties and nineties was heated, Culler posited that the invention of that Greece involved the suppression of the idea of Greece's dependence on Semitic cultures and on Egypt in particular. Clearly Culler's challenge in Bernal's shadow attacks the foundational nature of Western classical culture, the very Hellenism which philology and archaeology built and which, in turn, built it. Culler asks critically what will happen now that the ideological underpinnings of fields of inquiry such as classical archaeology, classicism and Hellenism find themselves under interrogation in the larger framework of multiculturalism and a politics of difference? He also questions the hermeticism and homogeneity of classical philology as a discipline and, like Bernal before him, he advocates a more cross-disciplinary, cross-regional epistemic, and theoretical practice.

Theories of reading in the present

Clearly, unreflexive textual practice negates the consequences of difference in past contexts and present societies. Because a focus on difference reflects on how social lives are inscribed by the experiences of gender, ethnicity, sexuality, and so on, it amounts to a theoretical threat to philology, as described and exemplified above. In parallel terms and no less relevant to archaeology, the emergence of a politicized and ethical archaeology recognizing its part in contemporary culture has been articulated through discourses of nationalism, sociopolitics, postcolonialism, diaspora and globalism. Such contextual readings have been shaped by anthropological and social theory. ${ }^{59}$ Lest we forget, these were set in motion not by philology (as in the eighteenth and nineteenth centuries) but largely by linguistic, literary, and cultural theories of reading from the sixties. And yet, in the case of archaeology, there has been 'a disciplinary reticence to embrace the politics of identity both in our investigations of the past and our imbrications of the present', which, as Lynn Meskell concludes, 'has much to do with archaeology's lack of reflexivity, both personal and disciplinary, concurrent with its antitheoretical approaches. ${ }^{60}$ Perhaps, Meskell speculates, this resistance to identity politics issues out of archaeology's lack of a personal narrative and the self-reflexive analysis of motive and practice more prevalent in anthropology. For the archaeologist, subjects have been long dead and there is none of the cult 
of exchange which exists between ethnographer and living people, and so such tactics of the field have only cursorily been explored..$^{61}$ The denial of subjectivity is reminiscent of the terms of philological practice, as outlined by Thomas cited above. However, beyond these tactics, there arise larger social and political settings that underlie both disciplines. Such issues have been addressed in a variety of theoretical ways within archaeology outside Greece in the terms of class inequality, gender bias, sexual specificity, heritage representation, selfhood, embodiment, being, disciplinarity etc. ${ }^{62}$ Philology has been forced, too, to open itself up to such thematics and approaches, as much for the survival of the discipline of classics as for aspiring to greater interdisciplinarity. In the words of one classicist, coming out of their discipline's own 'crisis, after confronting its roots in orientalism and a western-centered sense of destiny [many classicists] turned to contemporary discourse and the investigation of class, gender and ethnicity in antiquity, to revitalize a discipline'. ${ }^{63}$

The focus of this volume - nationalism - has also been explored in archaeology. ${ }^{64}$ And, of course, literary, critical and cultural studies have led the way in exploring such subjectivities since the sixties in ways that have marked critical practice in the Western academia. And while culturalist studies of nationalism have multiplied in Greece in the last decade or so, the impetus for the analysis of its role in identity from these fields issued in large part from a series of scholars from outside Greece. ${ }^{65}$ And, as noted earlier, they are regularly vilified by the standard-bearers of a deeply entrenched philological, positivistic, and nationalist rearguard.

Nowadays, in archaeology and philology, the agendas of difference that drive self-definition in such contrastive ways emphasize that difference and disenfranchisement lurk beneath categories of (national) belonging that heretofore drove the ideological epistemological agenda. It is evident that both disciplines, along with their reading strategies, emerged at a cultural juncture in the nascent Greek nation-state shaped by the necessities of 'belonging': at a moment when the modern Greeks sought to prove to themselves as much as to other Europeans that their history belonged to them. That is, to be more precise, that the history of Classical Greece that already belonged to northern Europeans also belonged to them, the modern Greeks. This raised a serious issue. In terms of its symbolic classical capital, was 'Greece the borrower or lender? The local source of global knowledge or its tardy imitator?'66 Archaeology and philology embodied and sought to overcome this very tension as both disciplines were nationalist and imperialist at one and the same time. (Symbolically, it is no accident that one of the Greek state's first public acts was to restore and raise a column from the Parthenon to mark the arrival of an externally-imposed and foreign new King of Greece.)

It is no surprise then that recent scholarship has begun to explore the effects of Europe's colonization of the Greek Ideal from the eighteenth century onwards and analyze what reverberations this might have had on the form of modern Greek modernity as a whole. ${ }^{67}$ Clearly, the restitution of classical Greece in forming modern Greece went hand-in-hand with the repression of all kinds of otherness, not least other elements of Greek modernity itself that formulated themselves beyond the classical paradigm. For the Greeks this amounted to a 'self-colonization' of sorts born out of the internalization of the lessons of Hellenism, which they perceived as foreign and native, both Other and the Same. ${ }^{68}$ In seeking discontinuities and the genealogies of contemporaneity beyond philology and archaeology's chief concerns, the critic lays down a set of urgent new contexts, whose study will engender new strategies of reading and interpreting our past and is in keeping with our present moment.

This article has tried to show how philology and archaeology were complicit, as disciplines that shared similar strategies at a specific moment, in Greek nation-building. At a very different moment in time now, a moment when diverse types of decolonization are working to open up new ways of thinking about and relating the centrisms of the past and imagine alternative possibilities, there may be a way for both to unhand themselves from the death grip of their unreflexive forms of reading. To launch a critique of the foundationalism inherent in such reading practice, it is necessary to realign the relative positions of text and context in terms that not only question what has been repressed and what foregrounded (and in whose terms), but also how one came to be given priority in the first place. The aim would be to theorize a relation of text/artefact and context that would respect the differential matrices of cultural history and, at the same time, ensure that texts/ artefacts are free to challenge and resist these subsuming contexts. In recalibrating this relationship, therefore, both archaeologists and philologists might very well seek guid- 
ance from a most unlikely place, from another mode of close reading-deconstruction. For it is from a rich vein in this reading practice that regarded itself 'a patient philological deconstruction' that one might find a problematization of the relation between the text and its 'political supplement', its context. ${ }^{69} \mathrm{I}$ have in mind Paul de Man's famous essay on 'The Return to Philology', wherein he defended theory by reaffirming the rhetorical complexities of reading. 'In practice,' de Man maintained, 'the turn to theory occurred as a return to philology, to an examination of the structure of language prior to the meaning it produces. ${ }^{70}$ This turn to the modalities of reception and production of meaning implied a sensitivity to the ways of context before text (as it were), and necessitated the creation of an autonomous space for self-reflexivity - theory - even as it hoped to restore readerly textual resistance in the face of these contexts. To put it another way, and more pragmatically so in an appreciation of de Man's contribution on this point, Jonathan Culler reflected that: 'we have the problem how to enlist literary works in the projects of multi-cultural education without foreclosing the problematic of reading by ceasing reading when the works stop saying what we expect them to say." ${ }^{11}$

Philology and archaeology may look here for some sustenance. However, it is safe to conclude that the interface of text and context at the level of a reading strategy will remain a thorn in the side of philology and archaeology just as it is, ironically enough, the bane of cultural studies. How does one relate works or texts to contemporaneous social institutions and non-discursive practices? How can one distinguish between text and context in light of poststructuralist notions that there is no-outside-the-text? Are social institutions and practices functions of a cultural system or vice versa? Do the former in this case diminish the latter or the other way round? And how, and on what basis, does one argue for the prioritization of 'synchronic' over 'diachronic' aspects of the relationship between texts/ artefacts and cultural systems?

\section{Reading the present in posterity}

This article began with a statement about satire and philology. It ends with a reflection on satire and archaeology. For, in the popular imaginary, the archaeologist is often invoked precisely at instances where the fit between text and context is at its most tenuous or absurd. In cartoons, for example, we often encounter the archaeologist called upon to decipher the meaning of the most uncategorizable of objects at a time far off in the future when the original codes of signification for such objects have long since passed and have been forgotten. In H.F. Ellis' 'Letter to Posterity' in The Atlantic Monthly (November 1955), for example, the author imagines the ways his skeleton and ballpoint pen will be deciphered by an archaeologist in AD 20,000. ${ }^{72}$ In such archaeological spoofing, the archaeologist - himself often idiosyncratically dressed and coiffed - stands as just as much a figure of authority as he is a figure of ridicule. He is cultural relativist and so versatile. This may make him more likely to be in touch with some other time long since past. Yet the expectation may also be that the archaeologist's pronouncements may very well be as wacky as the objects he is called upon to make sense of. For he is plainly out of touch with the one age he does inhabit. The archaeologist's precarious contact with the presentness of his own 'cultural system' is not without its significance for the plausibility of the interpretation that he might offer about a past time.

In precisely the terms of this cartoon, the reader might also travel two hundred years ahead into the future and look back on the interpretation of the present as an archaeological find. In this way the reader would be reproducing the terms of engagement that underlie the two-hundred year gap separating this article's interpretative locus from the eighteenth century that this article purports to examine. The thorny configurations of relationship that lie at the interface between cultural objects, texts and practices on the one hand and social, political, and economic processes on the other make textual or material mediation not simply contingent on but subsequent to processes of selection, preservation, and effacement.

What will future critics see? How will they combine text and context when they look back to decipher, say, the visual image of the Cycladic head as it emerges from the 'sea' at the opening ceremony of the Athens 2004 Olympic Games? How will critics or some form of futuristic visual archaeologists read this image synchronically, contextually? How will they relate its performance to the larger 'cultural system' of our own time? In other words, how will text and context interface and speak to the underlying poetics of national belonging or not belonging in 2004? Will the critic or archaeologist of the future 
read the image alongside the parade of Hellenic tableaux vivants as an invitation to share cultural patrimony in a game of national recognition? Or is the viewer indulging in liberal and post-modern games of identifying intertextual allusions in a society of the spectacle that has neutered all notions of participatory politics? Will the figure's digitized sophistication symbolize Greek society's success in aspiring to the highest technical standards of a coveted Western modernity at the beginning of the twenty-first century? Or will it be read as a pathetic example of colonial mimicry? Is it a moment in a Hellenic tale of belonging or unbelonging?
Vangelis Calotychos
Program in Hellenic Studies
Department of Classics
Columbia University
ec2268@columbia.edu

\section{NOTES}

*I first heard the felicitous term 'dead hand of philology' from Professor Michael F. Hendy, a Byzantine economist, at the University of Birmingham over twenty years ago. His critique of its damaging effects on his own field of Byzantine Studies struck me as especially poignant, coming as it did not from a scholar representing the then radical fringes of cultural studies, which had blossomed (or taken root depending on your perspective) at Birmingham during that time, but from a more conservative scholar, albeit one resistant in his own way. It was especially noteworthy that a social scientist was bemoaning how habits of philological reading were preventing us from aspiring to a fuller understanding of cultural, historical and socioeconomic contexts. Like classical philology, Byzantine Studies then, and up till now moreover, has been lamentably slow in rising to meet the challenges of modern theory or cultural studies. My recollection of Michael Hendy's phrase left its mark on this article long before I heard very unexpectedly and very sadly, at the time of its writing, of his sudden passing in May 2008. While the terms of my critique would no doubt have alienated him, judging from this phrase and its careful deployment in this epigraph, perhaps its spirit might have found some resonance with him. The epigraph recalls Michael Hendy's spirit and deep erudition, may he rest in peace.

\section{Grafton 1991, 215.}

2. Grafton 1991, 215.

3. When I used to vacation in Greece as I did most summers in the years that I was a student at university, friends and relatives would often ask me what, after all, was it that I was still studying at university and what might it lead to in terms of a career? The second part of their question was rather simple - 'A professor!' I answered, an answer I produced with greater and greater ease as the years went by. For, as time passed, I found that I was less and less qualified to imagine myself capable of doing anything else. The first part of their question was more difficult. Studying as I was in the eighties, I liked to think I was studying criticism, critical theory, and eventually comparative literature. Indeed, by the time I was a $\mathrm{PhD}$ student, I was a student in a department of comparative literature. Invariably, even amongst friends who had a university education, the question raised was what was being 'compared', which led me to argue that my field no longer entailed any comparison, or alternatively, that comparison came with too many assumptions that themselves had become the objects of this field's study. Soon the discussion was at an impasse and we proceeded to other matters. In time, and with maturity no doubt, I would just say that I studied logotechnia or 'literature', which only raised questions about whether I was writing a novel or a collection of poems. The answer was 'neither'. (Nothing was more loathsome than for someone to point out to you that you are therefore a critic, when the implication is that in their eyes this was second best and you could never aspire to be a writer.) Eventually, I would resort to the term 'filologos' that was accepted gleefully by my Greek interlocutors. That squared nicely with their own experience, both disciplinary and professional. It indicated clearly to my questioners - as far as the second part of the initial question above was concerned - that I did have a respectable, if very unexciting, future profession. However, it also elicited from my interlocutors a slew of questions about the etymology of words and references to the classical tradition, which, for me, a modernist and comparativist in the modern period, seemed out of place and pedantic - why not consult a dictionary instead? - as it alluded to origins and a world of verifiable fact, an assumption both Comparative Literature and I had long turned our backs on.

\section{Herzfeld 1986, 11.}

5. Alexiou 1990.

6. Wood 1827, ii.

7. Wolf 1985.

8. Wolf 1869.

9. Bernal 1987, 317.

10. Marchand 1996, 19.

11. Prickett 1986, 1 (my emphasis); quoted in Acosta 2006, 38 n. 12. 
12. Marchand 1996, 21.

13. Augustinos 1994 gives a readable commentary on many French travellers' narratives about Greece from this and other post-Renaissance periods.

14. Etienne \& Etienne 1992, 144-45.

15. Andrén 1998, 114.

16. Ruprecht 2002, 128.

17. Lamartine 1875,78 .

18. The celebrated and wildly popular model for this genre was A. Barthelémy's 1825 Travels of Anacharsis the Younger in Greece during the Middle of the Fourth Century before the Christian Era, 6 vols. \& a seventh in quarto containing maps, places, views, and illustrations of coins. For a discussion of its relation to a tradition of 'landscape writing' and affinity to Greek counterparts, especially Rhigas' Map of Greece (1797), see Calotychos 2003, Ch. 1.

19. Eisner 1991, 76.

20. Constantine 1986, 93.

21. Andrén 1998, 15.

22. Stark 1880 .

23. Schnapp 1993, 306-11.

24. Petrakos 2004, 3.

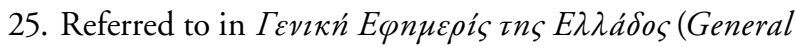
Gazette of Greece) 77, 17 November 1829); see Protopsaltis 1967, 110.

26. Kyriakos Pittakis (1798-1863) was Curator of Antiquities for Athens and, in 1833, Sub-Ephor for Antiquities of Greece.

27. Petrakos 2004, 50.

28. Hamilakis 2007, 101; cf. Voutsaki 2003, 249-50.

29. Hamilakis 2007, 101.

30. Of course, the means of production for Hellenic print culture was to be found in Venice and in other diaspora centres from the mid-fifteenth century onwards. However, the same was by no means true for that geographical part of the Greek world under Ottoman rule which was eventually liberated in 1830 . For an account of this activity, see, particularly, Staikos \& Sklavenitis 2001.

31. Politis 1984.

32. Kyriakidou-Nestoros 1978; Herzfeld 1986.

33. These reflections on linguistics and history at the University of Athens in the 1880s are inspired by an oral presentation by Effie Gazi entitled 'Creating National Disciplines,' which was delivered at a conference on 'Western Visions and the Construction of Identities in Southeast Europe', a workshop on the Late Ottoman Empire and the Balkans, held at Brown University, in April 2002.
34. Morris 1994, 11.

35. Elsewhere, too, archaeology may have played a minimal role in the construction of national identity. See, for instance, Schnapp's discussion of the French case: Cleziou et al. 1991.

36. Andrén 1998, 116.

37. Larsen 1988.

38. Andrén 1998, 119.

39. Kotsakis 1991, 67.

40. Morris 2000, 38.

41. Kotsakis 1991, 67.

42. Hamilakis $2007,45$.

43. Kotsakis 1991, 81.

44. Binford 1962; Flannery 1967; Clarke 1973.

45. Renfrew 1980, 291-92.

46. Snodgrass 2006, 65.

47. Snodgrass 2006, 34.

48. See Kotsakis 1991 on this issue. He lays great store by the work of G.H. Hourmouziadis.

49. This impulse may also be seen in philological mainstays of the comparativist tradition, who argued consistently for the full appreciation of material and social conditions of textual analysis. See, notably, Auerbach 1993, 5-24.

50. Selden 1990.

51. Thomas 1990, 69.

52. Thomas 1990, 70.

53. Thomas 1990, 70 .

54. Lambropoulos 2002, 45.

55. One may consult Sandys 1903 or Pfeiffer 1976 for histories or philological scholarship and methodology. But these do not constitute theoretical works.

56. Unfortunately, it stoops to a journalistic form of selfsatisfied, moralistic, and narcissistic criticism that is unworthy of rejoinder. It blithely parades its provincialism to protect the nation from 'universal' and/or 'global' values and so exemplifies many of the conventions of the genre previously delineated by Lambropoulos. If left unaddressed, it may only fester in the minds of the general readership and leave a mark in the form of a generally held impression. For a recent fatuous example, see K. Georgousopoulos in Ta Nea, 16 February 2008.

57. Culler 1990, 52.

58. Culler 1990, 51.

59. Clifford \& Marcus 1986; Gupta 1995; Geertz 1995; Clifford 1997; Gupta \& Ferguson 1997.

60. Meskell 2001, 279. 
61. Fotiadis 1993; Hodder 1999; Meskell 2001; Politis 2001.

62. See Meskell 2002 for an overview of developments in these areas.

63. Morris 2001, 11.

64. Trigger 1989; Hodder 1991; Kohl \& Fawcett 1995; Patterson 1995; Diaz-Andreu \& Champion 1996.

65. See Herzfeld 1986; Herzfeld 1987; Lambropoulos 1988; Lambropoulos \& Alexiou 1985; Tziovas 1986; Tziovas 1989; Jusdanis 1991; Faubion 1993; Leontis 1995; Gourgouris 1996; Van Dyck 1998; Peckham 2001; Calotychos 2003.

66. Just 1995, 289.

67. Calotychos 2003, 52.

68. Gourgouris 1996; Calotychos 2003.

\section{REFERENCES}

Acosta A.M. 2006: Reading Genesis in the Long Eighteenth Century: from Milton to Mary Shelley (Aldershot).

Alexiou M. 1990: Greek Philology: diversity and difference, in: Ziolkowski J. (ed.), On Philology (University Park and London).

Alexiou M. \& Lambropoulos V. (eds) 1985: The Text and its Margins: Post-Structuralist Approaches to Twentieth Century Greek Literature (New York).

Andrén A. 1998: Between Artifacts and Texts: Historical Archaeology in Global Perspective (transl. by A. Crozier; New York and London).

Ascher R. 1960: Archaeology and the public image, American Antiquity 25, 402-3.

Auerbach E. 1993: Literary Language and its Public in Late Antiquity and in the Middle Ages (Princeton).

Augustinos O. 1994: French Odysseys: Greece in French Travel Literature from the Renaissance to the Romantic Era (Baltimore and London).

Bernal M. 1987: Black Athena: the Afroasiatic Roots of Classical Civilization, I: The Fabrication of Ancient Greece, 1785-1985 (New Brunswick).

Binford L.R. 1962: Archaeology as Anthropology, American Antiquity 28, 217-25.

Calotychos V. 2003: Modern Greece: a Cultural Poetics
69. The terms quoted here struck me as highly topical, as they come from a very recent newspaper article by Stanley Fish, entitled 'French Theory in America' (The New York Times, 6 April 2008). The terms themselves are used by François Cusset, whose French Theory: how Foucault, Derrida, Deleuze and Co. Transformed the Intellectual Life of the United States is forthcoming from the University of Minnesota Press.

70. de Man 1986, 24.

71. Culler 2002, 15. The special issue of the Journal of Aesthetic Education 36(3) includes essays from a number of scholars who reflect on the significance of de Man's 'return to philology' in his discussion of theory. Barbara Johnson echoes and extends Culler's reading (Johnson 2002).

72. For reference to this article and a broader survey of the public image of the archaeologist, see Ascher 1960.

(Oxford and New York).

Clarke D.L. 1973: Archaeology: the loss of innocence, Antiquity 47, 6-18.

Cleziou S. et al. 1991: The use of theory in French archaeology, in: Hodder I. (ed.), Archaeological Theory in Europe: the Last Three Decades (London and New York) 129-60.

Clifford J. 1997: Spatial practices: fieldwork, travel, and the disciplining of anthropology, in: Gupta A. \& Ferguson J. (eds), Anthropological Locations: Boundaries and Grounds of a Field Science (Berkeley) 185-222.

Clifford J. \& Marcus G.E. (eds) 1986: Writing Culture: the Poetics of Ethnography (Berkeley).

Constantine D. 1986: Early Greek Travellers and the Hellenic Ideal (Cambridge).

Courbin P. 1982: Qu'est-ce que l'Archéologie?(Paris).

Crawford M.H. (ed.) 1983: Sources for Ancient History (Cambridge).

Culler J. 1990: Anti-foundational Philology, in: Ziolkowski J. (ed.), On Philology (University Park and London).

Culler J. 2002: The return to Philology, Journal of Aesthetic Education 36(3), 12-16.

de Man P. 1986: The Resistance to Theory (Minneapolis). Diaz-Andreu M. \& Champion T. (eds) 1996: National- 
ism and Archaeology in Europe (London).

Dyson S. 1981: A classical archaeologist's response to the 'New Archaeology', Bulletin of the American Schools of Oriental Research, 7-13.

Eisner L. 1991: Travelers to an Antique Land: the History and Literature of Travel to Greece (Ann Arbor).

Etienne R. \& Etienne F. 1992: The Search for Ancient Greece (New York).

Faubion J.D. 1993, Modern Greek Lessons: a Primer in Historical Constructivism (Princeton).

Flannery K.V. 1967: Culture history v. culture process: a debate in American archaeology, Scientific American 217, 119-22.

Fotiadis M. 1993: Regions of the imagination: archaeologists, local people, and the archaeological record in fieldwork, Greece, Journal of European Archaeology 1, 151-70.

Geertz C. 1995: After the Fact: Two Countries, Four Decades, One Anthropologist (Cambridge, MA).

Gourgouris S. 1996: Dream Nation: Enlightenment, Colonization and the Institution of Modern Greece (Stanford).

Grafton A. 1991: Defenders of the Text: the Tradition of Scholarship in an Age of Science, 1450-1800 (Cambridge, MA).

Gupta A. \& Ferguson J. (eds) 1997: Anthropological Locations: Boundaries and Grounds of a Field Science (Berkeley).

Hamilakis Y. 2007: The Nation and its Ruins: Antiquity, Archaeology, and National Imagination in Greece (Oxford).

Hatvany L. 1986: Die Wissenschaft des nicht Wissenswerten: ein Kollegienheft [1908] (with English annotations by A. Grafton \& preface by H. Lloyd-Jones; Oxford and New York).

Hendy M.F. 1985: Studies in the Byzantine monetary economy, c. 300-1450 (Cambridge).

Herzfeld M. 1986: Ours Once More: Folklore, Ideology, and the Making of Modern Greece (New York).

Herzfeld M. 1987: Anthropology Through the Looking Glass: Critical Ethnography in the Margins of Europe (Cambridge).

Hodder I. (ed.) 1991: Archaeological Theory in Europe: the Last Three Decades (London and New York).

Hodder I. 1999: The Archaeological Process: an Introduction (Oxford).
Johnson B. 2002: Art for something's sake, Journal of Aesthetic Education 23(3), 28-30.

Jusdanis G. 1991: Belated Modernity and Aesthetic Culture: Inventing National Literature (Minnesota).

Just R. 1995: Cultural certainties and private doubts, in: James W. (ed.), The Pursuit of Certainty: Religious and Cultural Formulations (London and New York) 285-308.

Kohl P.L. \& Fawcett C. (eds) 1995: Nationalism, Politics, and the Practice of Archaeology (Cambridge).

Kohl P.L. 1998: Nationalism and Archaeology: on the constructions of nations and the reconstructions of the remote past, Annual Review of Anthropology 27, 22346.

Kotsakis K. 1991: The powerful past: theoretical trends in Greek Archaeology, in: Hodder I. (ed.), Archaeological Theory in Europe: the Last Three Decades (London and New York) 65-90.

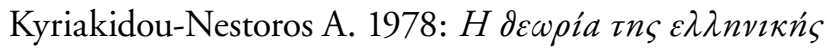

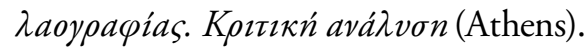

Lamartine A. de 1875: Souvenirs, Impressions, Pensées et Paysages Pendant un Voyage en Orient 1832-3 ou Notes d'un Voyageur (Paris).

Lambropoulos V. 1988: Literature as National Institution: Studies in the Politics of Modern Greek Criticism (Princeton).

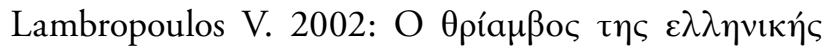

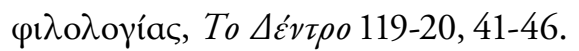

Larsen M.T. 1988: Introduction: literacy and social complexity, in: Gledhill J. et al. (eds), State and Society: the Emergence and Development of Social Hierarchy and Political Centralization (London) 173-91.

Leontis A. 1995: Topographies of Hellenism: Mapping the Homeland (Ithaca and London).

Marchand S.L. 1996: Down from Olympus: Archaeology and Philhellenism in Germany, 1750-1970 (Princeton).

Meskell L.M. 2001: The practice and politics of archaeology in Egypt, in: Cantwell A.M. et al. (eds), Ethics and Anthropology: Facing Future Issues in Human Biology, Globalism, and Cultural Property (New York) 14669.

Meskell L.M. 2002: The intersections of identity and politics in Archaeology, Annual Review of Anthropology 31, 279-301.

Morris I. 1994: Archaeologies of Greece, in: Morris I. 
(ed.), Classical Greece: Ancient Histories and Modern Archaeologies (Cambridge) 8-47.

Morris I. 2000: Archaeology as Cultural History: Words and Things in Iron Age Greece (Malden, MA and Oxford).

Morris S.P. 2001: Beyond continuity: confronting NeoHellenism in a Classical World, Journal of the Hellenic Diaspora 27, 7-18.

Patterson T.C. 1995: Toward a Social History of Archaeology in the United States (Orlando, FL).

Peckham R.S. 2001: National Histories, Natural States: Nationalism and the Politics of Place in Greece (London and New York).

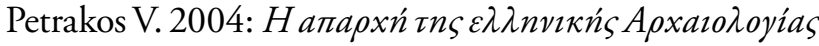

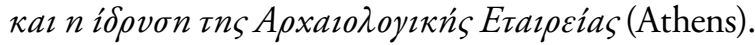

Pfeiffer R. 1976: History of Classical Scholarship from 1300 to 1850 (Oxford).

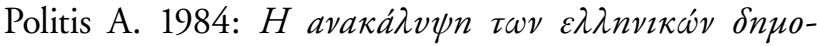

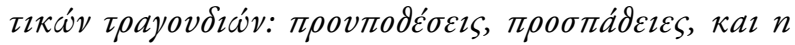

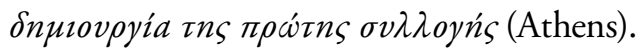

Politis G. 2001: On archaeological praxis, gender bias and indigenous peoples in South America, Journal of Social Archaeology 1, 90-107.

Prickett S. 1986: Words and "the Word": Language, Poetics, and Biblical Interpretation (Cambridge).

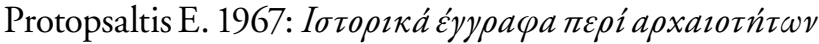

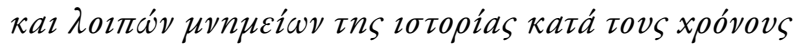

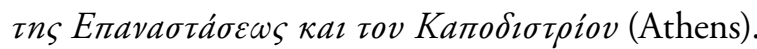

Renfrew C. 1980: The Great Tradition versus the Great Divide: Archaeology as Anthropology?, American Journal of Archaeology 84, 287-98.

Ruprecht L.A. 2002: Was Greek Thought Religious? On the Use and Abuse of Hellenism: from Rome to Romanticism (New York).

Sandys J.E. 1903-08: A History of Classical Scholarship, 3 vols (Cambridge).

Schnapp A. 1993: La conquête du passé: aux origines de l'archéologie (Paris).

Selden D. 1990: Classics and contemporary criticism, Arion 1 (third series), 155-78.

Snodgrass A. 2006: Archaeology and the Emergence of
Ancient Greece: Collected Papers on Early Greece and Related Topics (1965-2002) (Edinburgh).

Spon J. 1679: Voyage d'Italie, de Dalmatie, de Grèce, et du Levant, fait aux années 1675 et 1676...., 3 vols (Lyon).

Staikos K. \& Sklavenitis T. 2001: The Publishing Centres of the Greeks: from the Renaissance to the Neohellenic Enlightenment (Athens).

Stark C.B. 1969: Systematik und Geschichte der Archäologie der Kunst [1880] (Munich)

Thomas R.F. 1990: Past and future in Classical Philology, in: Ziolkowski J. (ed.), On Philology (University Park and London).

Trigger B.G. 1989: A History of Archaeological Thought (Cambridge).

Tziovas D. 1986: The Nationism of the Demoticists and its Impact on their Literary Theory (1888-1930) (Amsterdam).

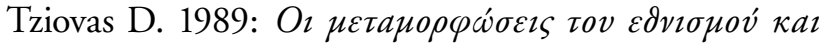

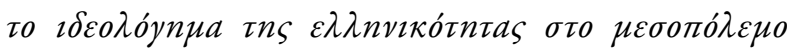
(Athens).

Van Dyck K.R. 1995: Kassandra and the Censors: Greek Poetry Since 1967 (Ithaca and London).

Voutsaki S. 2003: Archaeology and the construction of the past in nineteenth century Greece, in: Hokwerda H. (ed.), Constructions of the Greek Past: Identity and Historical Consciousness from Antiquity to the Present (Groningen).

Wiseman J. 1983: Conflicts in Archaeology: education and practice, Journal of Field Archaeology 10, 1-9.

Wolf F.A. 1869: Darstellung der Altertumswissenschaft, in: Bernhardy D. (ed.), Kleine Schriften 2 (Halle) 786875.

Wolf F.A. 1985: Prolegomena to Homer (transl. by A. Grafton et al.; Princeton).

Wood R. 1827: The Ruins of Palmyra and Baalbec (London).

Ziolkowski J. (ed.) 1990: On Philology (University Park and London).

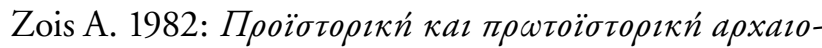
$\lambda$ oyía (Ioannina). 